\title{
Gravelometric image analysis of sediments (Prahova River, Romania)
}

\author{
Daniela Elena GOGOAŞE NISTORAN ${ }^{1}$, Livioara BRAŞOVANU ${ }^{2}$, \\ Cristina Sorana IONESCU ${ }^{1}$, Iuliana ARMAȘ ${ }^{2}$, Andrei COZMA ${ }^{1}$ \\ ${ }^{1}$ University Politehnica of Bucharest, Faculty of Power Engineering, Romania, \\ ${ }^{2}$ University of Bucharest, Faculty of Geography, Romania \\ dnistoran@gmail.com
}

\begin{abstract}
The paper presents a method of sediment gradation using the Basegrain software to analyse pictures taken from the bed surface in 20 locations along the upper course of Prahova River, Romania. Sediment grading curves and median diameter, median diameter (d50) values for each sample, obtained by the virtual sieving method were compared with the ones obtained through the Wolman - pebble-count method along a shorter reach. Results show a good match between the two methods.
\end{abstract}

Keywords: image analysis, Wolman method, sediment grading curves, mean diameter, virtual sieving

\section{INTRODUCTION}

It is well-known that field surveys for volumetric sampling and subsequent laboratory sieving of grain sediments from riverbed channel are very time and resource consuming, requiring equipment, staff and facilities for sampling, transporting, drying, weighting and processing. Moreover, the measurements can mostly be performed during summer, thus imposing a time constraint on researchers (Stähly et al., 2017).

During the last years many researchers have developed a series of image-processing techniques for analysis and classification of riverbed surface and armor layer sediments of mountain rivers (Buscombe, 2010; Graham, 2005; Weichert, 2004; Hate and Shelke, 2016; Rüther et al., 2013; Groom et al., 2018). They compared these virtual sieving results with the ones from classical methods such as sieving and weighting, individual pebble measurement with gravelometers or calipers, which are more consuming in terms of time and effort. (Rüther et al., 2013; Stähly et al., 2017)

A major advantage of the optical-processing techniques is they require limited resources, only for taking pictures with a camera and a computer. Furthermore, a large number of digital samples can be acquired during the warm season, thus eliminating the need of transport and storage. The pictures can be processed during the cold season.

Therefore, object-detection software for quantitative analysis of images were developed similar to the ones used for biology microscopic applications (such as pattern/colour recognition, cell counting, classification, clustering, sizing and/or morphological analysis). Platforms like Matlab, Image $\mathbf{J}$ (Java based) are the most used for image analysis (Rishi, 2015). In the present paper the freeware Basegrain software is used, which is based on computer algorithms under Matlab (Hate and Shelke, 2016; Deter and Weitbrecht, 2012).

Since the riverbed surface material of upper Prahova River is coarse enough to allow identification and delimitation of each particle in a picture, such an image-processing method was used to obtain the sediment grading curves in multiple locations along this study reach.

The objective of the paper is to assess the usefulness of the imagistic method for determining the sediment gradation curves and median diameter 
of multiple samples taken from the surface layer of the exposed sediment side bars along the upper course of Prahova River. A comparison with results obtained through the Wolman (pebble count) method is made to verify its accuracy (Bunte et al., 2009).

\section{STUDY AREA}

The $56 \mathrm{~km}$ course of Prahova River stretches from its source (at Predeal locality) to the downstream junction with Doftana tributary, near Campina locality. At the exit of the Carpathian reach the river passes through a narrow gorge, the Sinaia-Posada defile (Fig. 1).

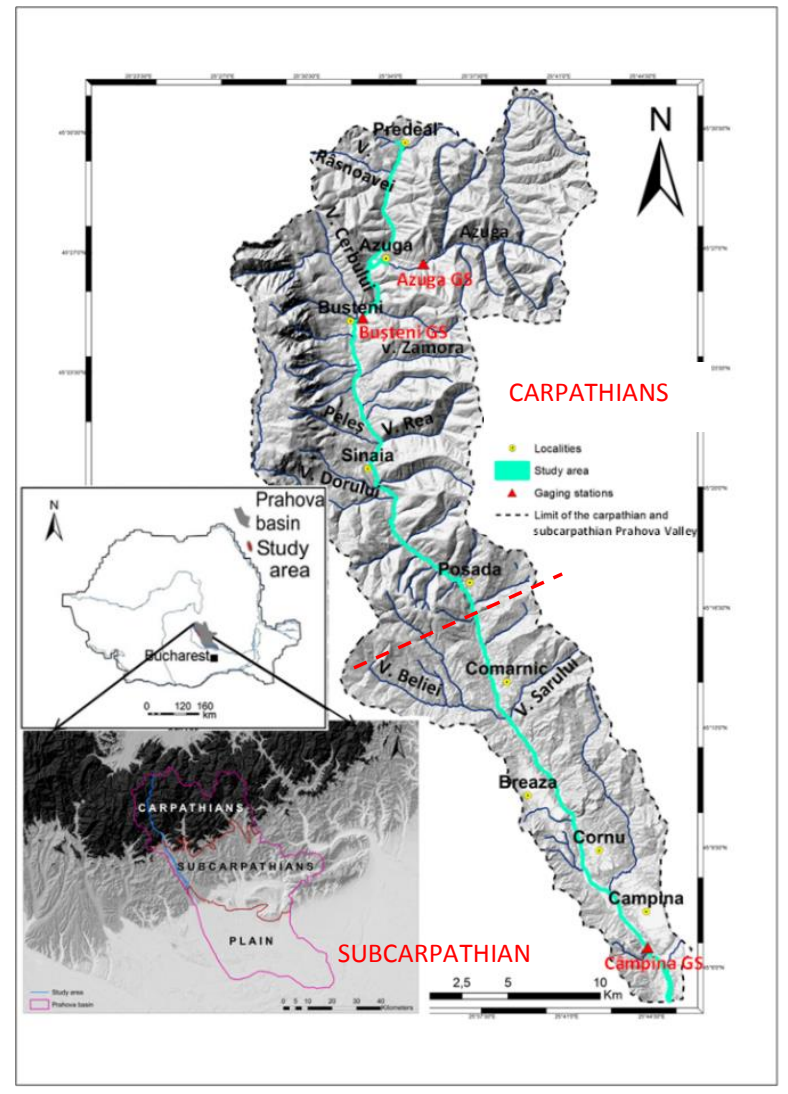

Figure 1 Upper course of Prahova River, with main tributaries; Carpathian and Subcarpathian reaches

Along the Carpathian river reach the morphological pattern of the Prahova River is mainly sinuous, with longitudinal side bars (Leopold and Wolman, 1957). Mean thalweg slope is about $1.25 \%$, sinuosity index is 1.14 and average main channel bankfull width is about $17 \mathrm{~m}$ (Braşovanu et. al, 2018; Armas et al., 2012). Along the Subcarpathian river reach the thalweg slope is about $1.17 \%$ and the morphological pattern has changed due to heavy anthropogenic pressures within the last century, from braided to a mixture of braided and single-thread (mean sinuosity index 1.06) with deep incisions up to 3-5 $\mathrm{m}$ in the thalweg (Armaş, 2012; Braşovanu, 2018; Ioana-Toroimac et al., 2015; Ioana-Toroimac 2014). However, there are areas where multiple lateral channels still exist, particularly towards the downstream junction with Doftana River. Main braiding index along the downstream reach is $1.75-2.72$, whereas average main channel bankfull width increases to $28 \mathrm{~m}$. The sediment from the bed is a mixture of sand, gravel and boulders.

\section{METHOD}

To investigate the grain size variation in the surface layer, we performed two field surveys along the study reach of the Prahova River. First one was undertaken 2012 to apply the Wolman method for the Subcarpathian Comarnic-Câmpina reach and the second one in 2017 to apply the image-processing method for the entire upper course of the Prahova River.

The Wolman's - Pebble Count method was used to perform the granulometric analysis of the Prahova bed surface deposits from side bars, (Wolman, 1954ș Leopold et. al., 1964; Kondolf, 1992, 1997). The technique consists in the random selection and measurement of sediment particles removed from the riverbed surface by an observer, who walks across the streambed and samples at each three steps, without looking, the first particle encountered at his/her toe (Bunte and Steven, 2001). The method was applied using zig-zag paths to allow sampling particles from riffles, pools and meander bars (Olsen et. al., 2005; Bunte et al., 2009). The entire $18 \mathrm{~km}$ reach was divided into six sampling sub-reaches chosen after thorough in-situ visual inspection in accordance with their either erosion or deposition character (Fig. 2). 


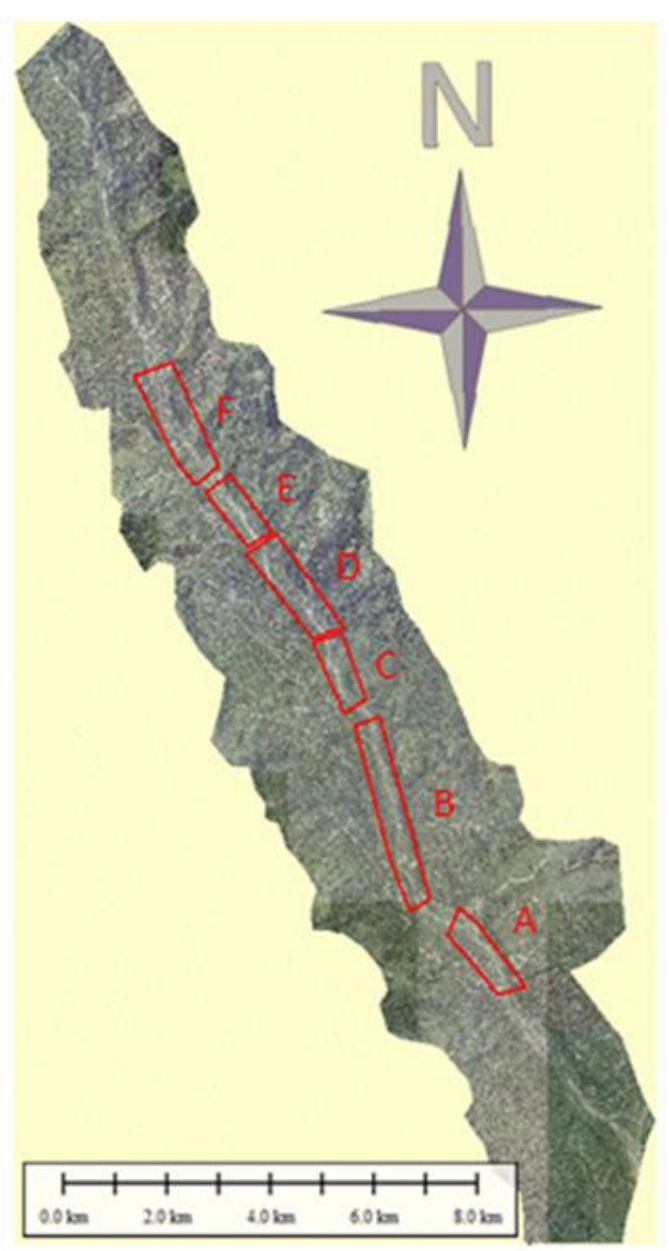

Figure 2 Pebble count method sampling subreaches

870 sediment particles were sampled along these sub-reaches as shown in Table 1 , for which the intermediate diameter was measured with a calliper and recorded.

Table 1 No. of samples within each sub-reach

\begin{tabular}{|l|l|}
\hline Subreaches & Number of samples \\
\hline A. Campina - L. Cornului & 121 \\
\hline B. L. Cornului - Cornu & 145 \\
\hline C. Cornu-Breaza & 154 \\
\hline D. Frasinet-Nistoreşti & 158 \\
\hline E. Pl. Cornului - G. Beliei & 171 \\
\hline F. Podul Corbului - Comarnic & 121 \\
\hline total & 870 \\
\hline
\end{tabular}

For the image-processing method 20 equallyspaced sampling locations were selected, at a relative mean distance of $3 \mathrm{~km}$ (Fig. 3). These were placed on exposed natural and accessible areas (during the low flow periods) of approximately 1 $\mathrm{m}^{2}$, situated on side bars or mid-channel bars, close to the water limit (Radoane et al., 2008). In all the sampling locations a coarse surface sediment layer (with coarse gravel and cobbles) was identified, beneath which a finer sediment layer (of finer gravel and sand) was found.

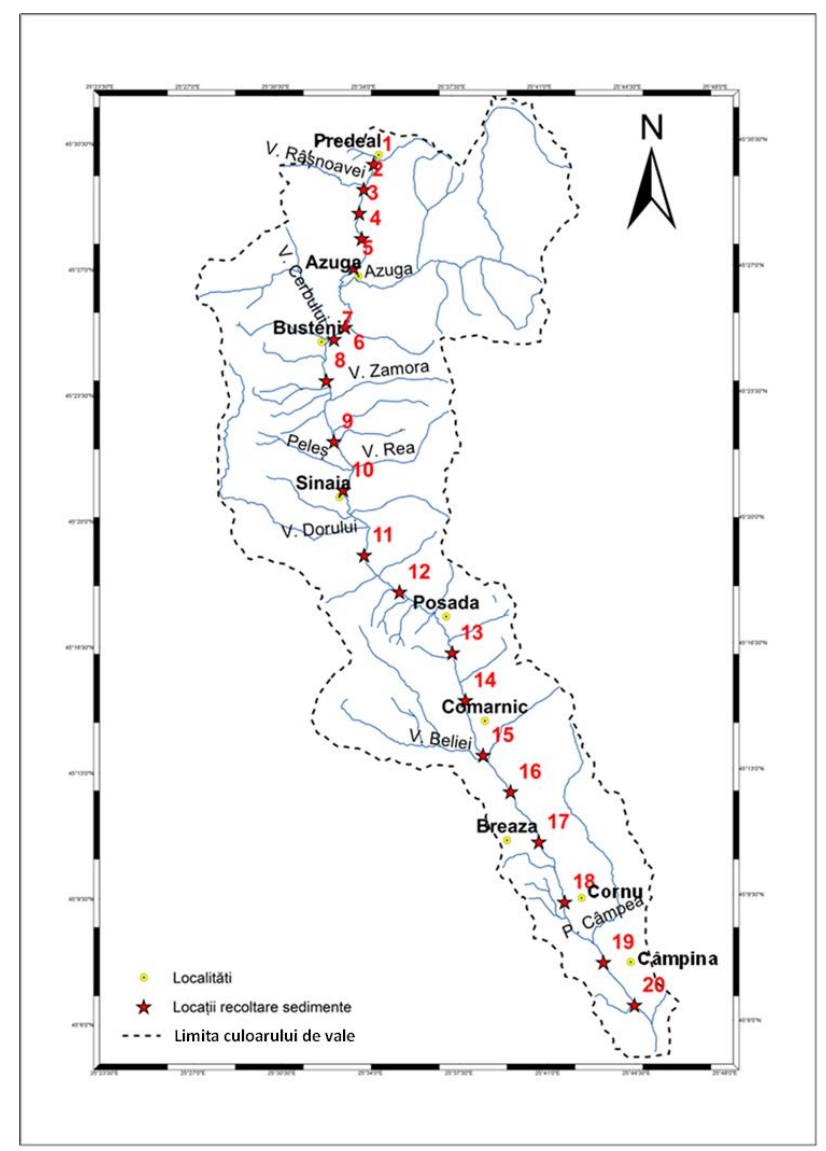

Figure 3 Sediment pictures sampling locations along Prahova River reach

The sampling method consisted in taking pictures of the riverbed surface as vertical as possible in order to minimize the angular distortions. Pictures were taken inside of two aluminium $50 \mathrm{~cm} \times 50 \mathrm{~cm}$ frames, one of them provided with a $5 \times 5 \mathrm{~cm}$ wiring mesh / network for quick visual inspection.

For the image analysis the Basegrain software version 2.2.04, written in Matlab (Detert and Weitbrecht, 2013) was used. For each location the most representative picture was processed.

After the calibration of dimensions along two rectangular axes, the image processing algorithms implemented into the software allowed the identification of interstices and particle edges (Detert and Weitbrecht, 2012). Within the picture 
taken through the frame without mesh, a smaller rectangular area was selected to calibrate the image identification parameters. Filtering thresholds were progressively adjusted for an optimal identification of particle edges and surfaces as well as the gaps between them.

When the grains cannot be correctly identified by the Basegrain software because of their nonuniform colours (stripes, spots etc.) each particle can be re-coloured by using a usual picture processing software. Also, in case of incorrect identification of particles, the software allows merging or splitting the processed areas by their actual edges.

The morphometric characteristics of each particles can be identified, such as: maximum and minimum diameter ( $a$ and $b$ ), their aspect ratio $(a / b)$, inclination angle of the axis along the maximum length with the horizontal direction, area, perimeter and mass center coordinates, and the sediment grading curve with main characteristic diameters: $d_{30}, d_{90}$ and mean diameter, $d_{50}$, (Fig. 4).

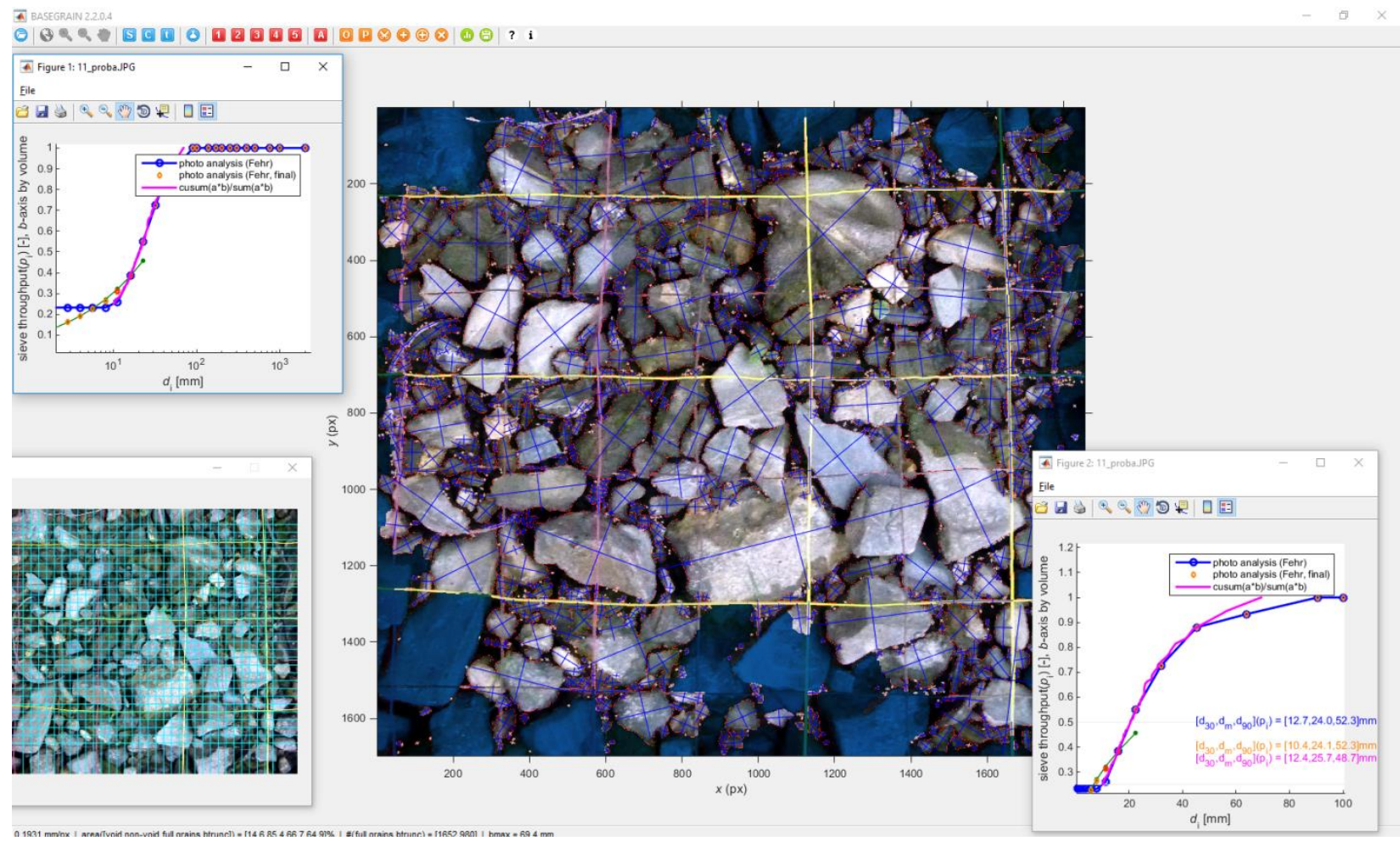

Figure 4 Example of virtual sieving through image processing technique with Basegrain software (Prahova River bed sample)

\section{RESULTS}

For each sub-reach along the Subcarpathian Prahova River where the Wolman method was applied, a cumulative size distribution curve of the particle diameters was determined according to the Wentworth grain size scale and represented in a plot in Figure 5. The results show that Prahova River has within its Subcarpathian reach a gravel bed surface with a sedimentary mixture of sand, boulders and mainly pebbles with a $d_{50}$ between 22 and $33 \mathrm{~mm}$. From these curves the mean diameter of the samples can be directly determined along each surveyed sub-reach.

Results obtained from the Basegrain image analysis software were saved in an Excel file as a table containing for each sediment particle its number and all the aforementioned morphological parameters. 


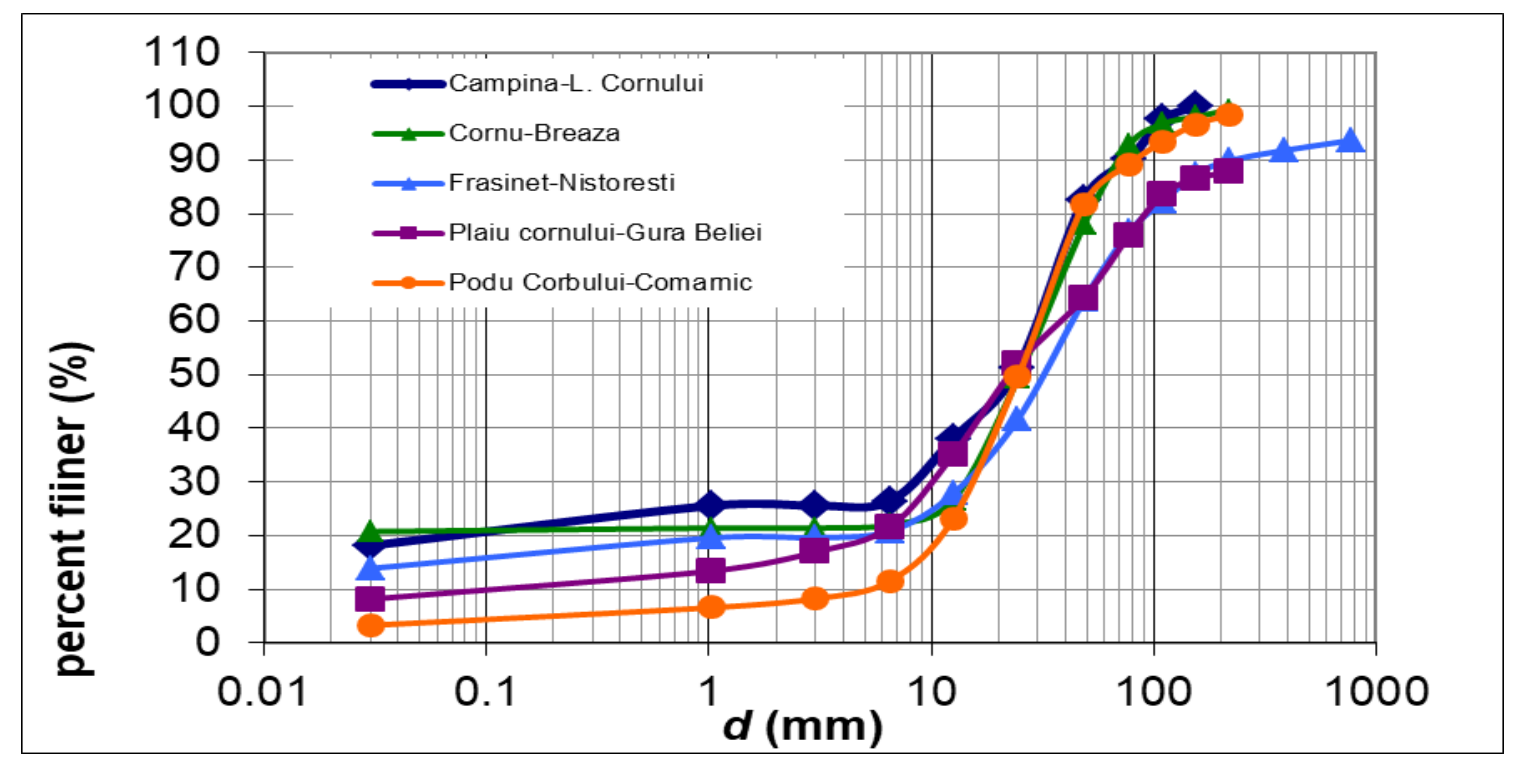

Figure 5 Pebble count method sampling sub-reaches

All these data were further on classified into grain size ranges through virtual sieving from which a granulometric curve is obtained. The diameter axis of the curve can be displayed using linear or base-10 log scale (Fig. 6). The Basegrain software computes the diameters of granulometric fractions by using 6 formulas. In this paper, an average of these values was used to represent the granulometric curves for all sampling sites (Fig. 6).

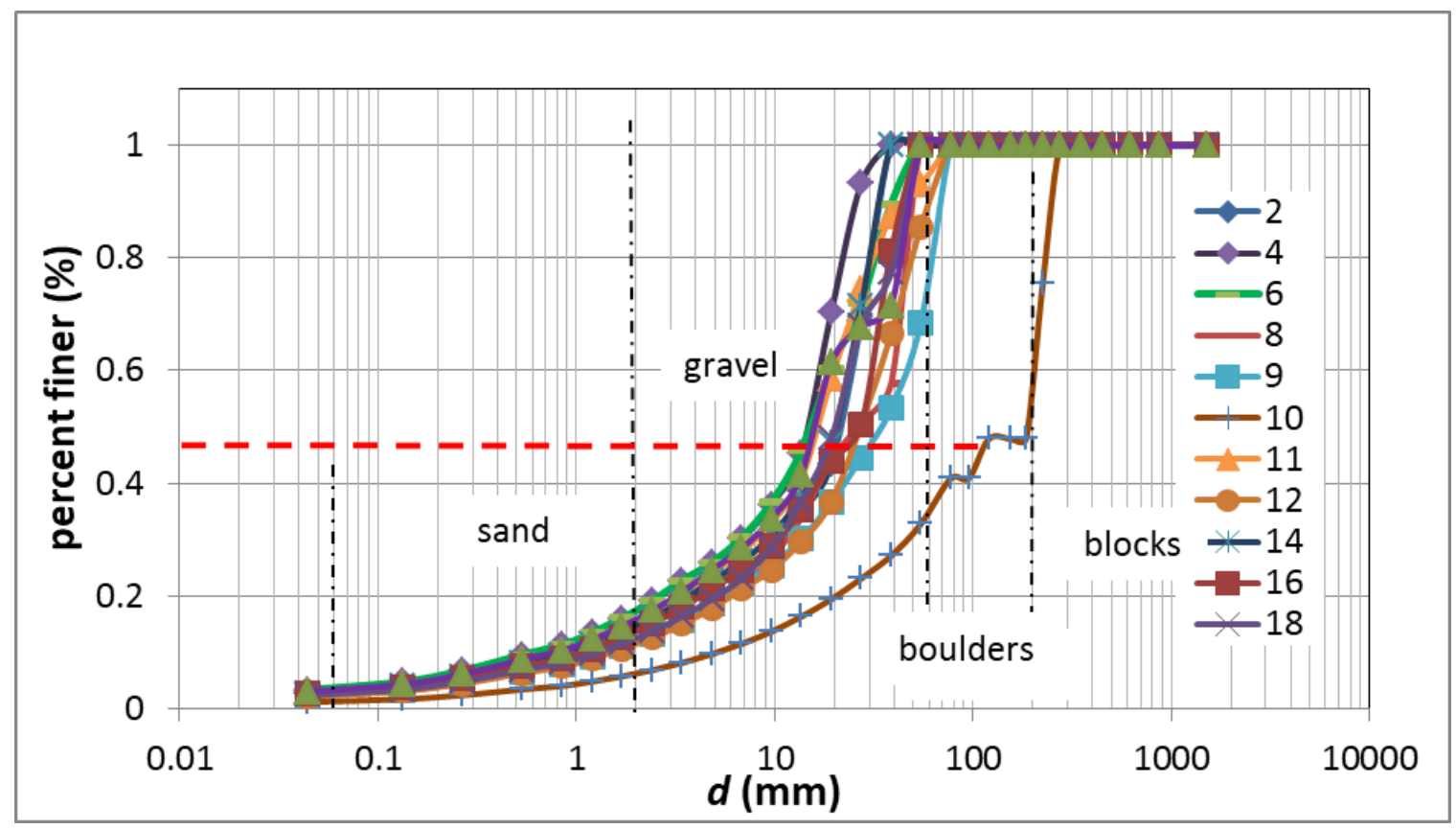

Figure 6 Granulometric curves through "virtual sieving"

The mean diameter, $d_{50}$, for the samples falls within the range $15-32 \mathrm{~mm}$ (specific to gravels), with one exception in location 10, where a much larger value of $155 \mathrm{~mm}$ was obtained (Table 2).

It should be emphasized that this maximum value of the mean diameter was registered downstream the Sinaia 0 dam (at the bridge, downstream the broad-crested spillway), thus proving the importance of anthropogenic impact on the solid transport of river. Therefore, this value, attributed to the human impact, was removed. 
Table 2 Selected locations and pictures taken through the mesh $50 \times 50 \mathrm{~cm}$ frame with mesh

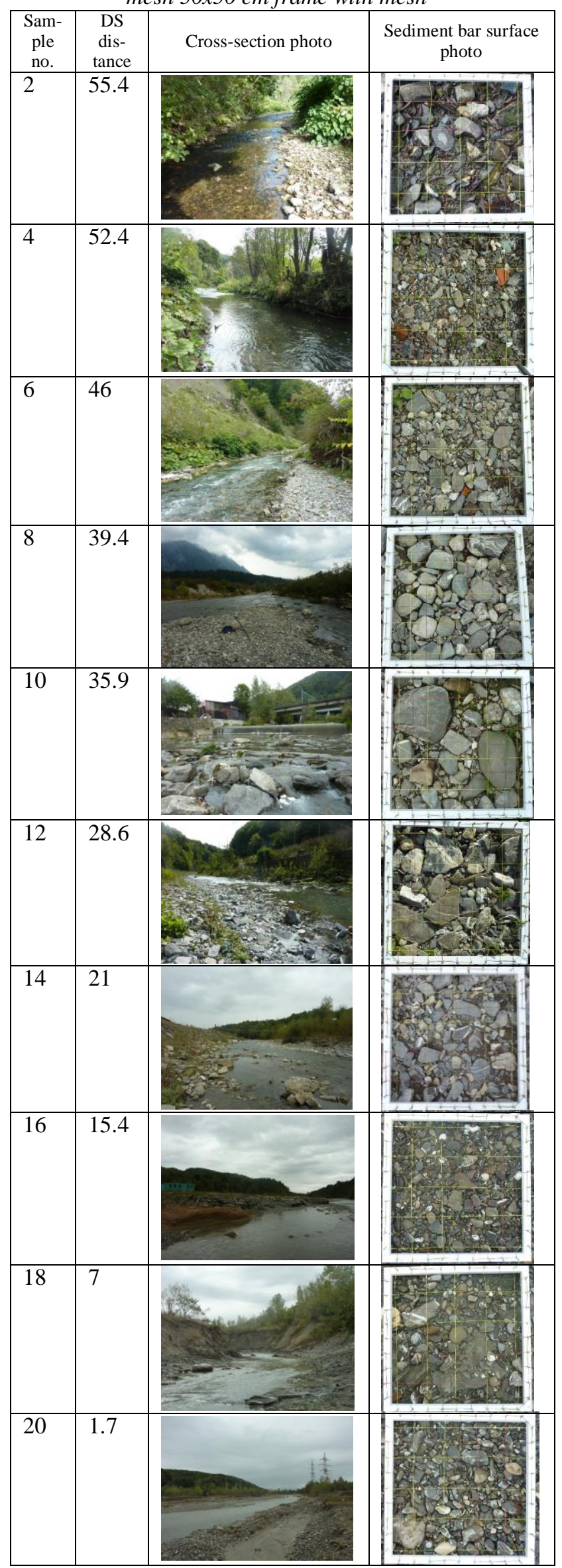

The $d_{50}$ values resulted from the image processing method were compared with the same values obtained from Wolman method along the downstream Câmpina-Comarnic river reach. A good match between the results of the two methods may be seen in Figure 7. In both Table 2 and Figure 7 the downstream (DS) distance is used, with respect to the confluence of Prahova River with its Doftana tributary.

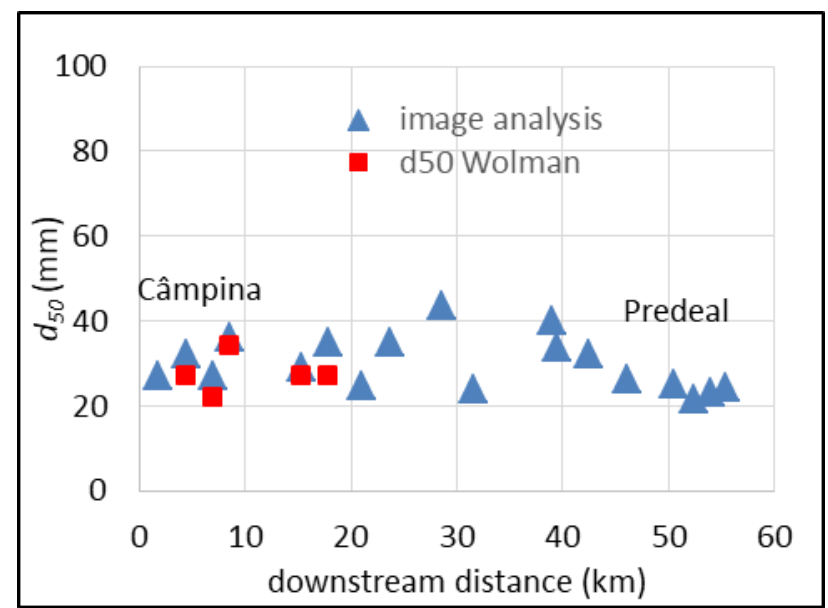

Figure 7 Mean diameter along Prahova River reach through image-processing and Wolman methods

\section{CONCLUSIONS}

One can see from Figure 7 that the mean diameter of the riverbed surface, resulted through the image processing method is only slightly smaller than the one obtained through the Wolman pebble count method. Stähly et al. (2017) provided a 0.83-0.86 ratio between the diameters obtained through the virtual siving and classical sieving methods. Bunte and Abt (2001) state that using the Wolman technique, particles finer than $4 \mathrm{~mm}$ are lost. These conclusions are in accordance with our results. Even though Graham et al. (2010) and Strom et al. (2010) showed the image processing method provides an accuracy similar to classical methods for seven distinct rivers, having different lithological and granulometric riverbed material, they suggested to process multiple pictures from the same location. This is recommended particularly because the sedimentation pattern at the upstream or downstream ends of the sediment bars can be different. 


\section{REFERENCES}

Armaş, I., Nistoran D. E., Brașovanu L. (2012), Catena, 100, pp. 83-99

Brașovanu, L. (2018), Morphodynamic study of Prahova River Channel along Carpathian and Subcarpathian reaches (in Romanian), PhD Thesis, University of Bucharest, Faculty of Geography, Bucharest, Romania

Braşovanu, L, Gogoașe Nistoran D. E., Armaş I. (2018) Hydrological characteristics of upper Prahova River, GeoPatterns, vol. 3, issue 1, pp. 32-42

Bunte, K. and Abt S.R., (2001), Sampling Frame for Improving Pebble Count Accuracy in Coarse GravelBed Streams. Journal of the American Water Resources Association 37(4), pp. 1001-1014.

Bunte, K., Abt., S.R., Potyondy., J.P., Swingle, K.W. (2009), Comparison of three Pebble Count Protocols (EMAP, PIBO, AND SFT) in two mountain gravel-bed streams. Journal of the American Water Resources Association, Vol. 45, No. 5, pp. 1209-1227

Buscombe, D., Rubin, D.M., Warrick, J.A. (2010). A universal approximation of grain size from images of non-cohesive sediment. Journal of Geophysical Research,115(F02015).

Detert, M., Weitbrecht V. (2012), Automatic object detection to analyze the geometry of gravel grains - a free stand-alone tool. River Flow 2012, R.M. Muños (Ed.), Taylor \& Francis Group, London, pp. 595-600

Detert, M., Weitbrecht V. (2013), User guide to gravelometric image analysis by BASEGRAIN.Advances in River Sediment Research Fukuoka et al. (eds), 2013, Taylor \& Francis Group, London, ISBN 978-1-138-00062-9.

Graham, D.J., Rollet, A.-J., Piégay, H., Rice, S.P. (2010), Maximizing the accuracy of image-based surface sediment sampling techniques: Key issues. Water Resources Research, 46, W02508, ref. 41, DOI: 10.1029/2008WR006940

Groom, J, Bertin, S., Heide F. Assessing Intra-Bar Variations in Grain Roughness Using Close-Range Photogrammetry, (2018) Journal of Sedimentary Research , 88 (5): 555-567, doi: /10.2110/jsr.2018.30

Hate A.N. and Shelke S. (2016), Sediment classification using image processing, International Journal of Advances in Elecronics and Computer Science, vol. 3, issue 2, pp. 74-77

Ioana-Toroimac, G., (2014). La Dynamique Hydrogéomorphologique De La Rivière Prahova : Fonctionnement Actuel, Évolution Récente Et Conséquences Géographiques, ISBN 978-606-28-0138$0,10.5682 / 9786062801380$.

Ioana-Toroimac, G., Zaharia L., Minea G., (2015), Using Pressure And Alteration Indicators To Assess
Morphological Quality: Case Study Of The Prahova River (Romania), Water, 7, 2971-2989; doi:10.3390/w7062971

Kondolf, G.M. (1992), The Pebble Count Technique for Quantifying Surface Bed Material Size in Instream Flow Studies, Rivers, 3, pp. 80-87

Kondolf, G.M. (1997), Application of the Pebble Count: Notes on Purpose, Method and Variants. Journal of the American Water Resources Association 33(1):79-87.

Leopold, L.B., Wolman, M.G., Miller, J.P. (1957), River channels Patterns, braided, meandering and straight, US Geological Survey Professional Paper, 282-B, IV, pp. 39-85

Leopold, L.B., Wolman, M.G., Miller, J.P. (1964), Fluvial Processes in Geomorphology, Freeman, San Francisco. Olsen, D.S., Roper, B.B., Kershner, J.L., Henderson, R., Archer, E. (2005), Sources of Variability in Conducting Pebble Counts: Their Potential Influence on the Results of Stream Monitoring Programs. Journal of the American Water Resources Association 41(5):1225-1236

Rădoane, M., Rădoane, N., Dumitriu, D., Cristea, I. (2008), Granulometry of Sediment Deposits from Prut River Channel between Orofteana and Galați (In Romanian - Granulometria depozitelor abie ale raului Prut intre Orofteana si Galaţi), Revista de Geomorfologie a Universității din București, pp 53-64

Rishi, N.R. (2015), Particle Size and Shape Analysis using Imagej with Customized Tools for Segmentation of Particles, International Journal of Engineering Research and Technology, vol. 4, 11, pp. 247-250

Rüther N. Huber, S., Spiller S., Aberle J., (2013), Verifying a photogrammetric method to quantify grain size distribution of developed armor layers, Proceedings of 2013 IAHR Congress (C) 2013 Tsinghua University Press, Beijing

Stähly, S., Friedrich, H., Detert, M. (2017). Size Ratio of Fluvial Grains' Intermediate Axes Assessed by Image Processing and Square-Hole Sieving, Journal of Hydraulic Engineering Volume 143 Issue 6, p.06017005-1-06017005.

Strom, K.B., Kuhns, R.D., Lucas, H.L. (2010), Comparison of automated photo grain sizing to standard pebble count methods, Journal of Hydraulic Engineering, 136(8), 461-473.

Weichert, R., Wickenhäuser, M., Bezzola, G.R., Minor, H.-E. (2004), Grain size analysis for coarse river beds using digital imagery processing. River Flow 2004, Naples, Italy, pp. 753-760.

Wolman, M.G. (1954), A method of sampling coarse river-bed material. Transaction Geophisical Union 35, pp. 951-956. 